\title{
Pengembangan Literasi Digital untuk Meningkatkan Kemampuan Membaca
}

\author{
Sri Fatikha Khoeriyah \\ SDN Paguyangan 01 \\ fatikha1719@gmail.com
}

\section{Article History \\ received 3/12/2020}

\begin{abstract}
The rapid development of technology today should be the main key in efforts to develop students' abilities and skills in the field of education and the learning process in dealing with the world of technology and information. The support and role of education is expected to increase the nation's competitiveness in the midst of global competition. The openness of information technology should be balanced with the progress of good reading literacy, but in Indonesia in particular, reading literacy skills for children are still at the bottom. Therefore, the development of digital literacy is expected to be a benchmark and a supporting factor in the development of student knowledge that can be accessed by digital media around the environment such as mobile phones, computers, laptops, etc. This article proposes a new conceptual framework for the concept of digital literacy, combining five types of literacy: (a) photovisual literacy; (b) reproductive literacy; (c) information literacy; (d) branched literacy; and (e) socio-emotional literacy that can support knowledge development.
\end{abstract}

Keywords: digital literacy, reading ability

\begin{abstract}
Abstrak
Abstrak dalam bahasa Indonesia mengikuti kaidah dalam Pedoman Umum Ejaan Bahasa Indonesia (PUEBI)Pesatnya perkembangan teknologi sekarang ini mestinya menjadi kunci utama dalam upaya untuk mengembangkan kemampuan dan keterampilan diri peserta didik dalam bidang pendidikan dan proses pembelajaran dalam menghadapi dunia teknologi dan informasi. Dukungan dan peran pendidikan diharapkan dapat meningkatkan daya saing bangsa di tengah persaingan global. Keterbukaan teknologi informasi seharusnya diimbangi dengan kemajuan literasi membaca yang baik, namun di Indonesia khususnya, kemampuan literasi membaca bagi anak masih berada di urutan paling bawah. Oleh karena itu, Pengembangan Literasi digital diharapkan dapat menjadi tolak ukur dan faktor pendukung dalam pengembangan pengetahuan peserta didik yang dapat diakses dengan media-media digital di sekitar lingkungannya seperti, handphone, komputer, laptop, dll. Artikel ini mengusulkan kerangka konseptual baru untuk konsep literasi digital, yang menggabungkan lima jenis literasi: (a) literasi fotovisual; (b) literasi reproduksi; (c) literasi informasi; (d) literasi bercabang; dan (e) literasi sosial-emosional yang dapat mendukung pengembangan pengetahuan.
\end{abstract}

Kata kunci: digital literasi, kemampuan membaca

Social, Humanities, and Education Studies (SHEs): Conference Series https://jurnal.uns.ac.id/shes

p-ISSN 2620-9284

e-ISSN 2620-9292 


\section{PENDAHULUAN}

Kemajuan IPTEK dalam sebuah bidang teknologi informasi dan komunikasi sekarang menimbulkan dampak yang sangat besar di antaranya yaitu mampu memudahkan dalam mencari atau mendapatkan suatu informasi. Teknologi digital ini mulai digunakan oleh anak-anak sejak usia dini. Balita berusia dua tahun secara teratur menonton film dan video, bermain game dan mendengarkan musik di komputer tablet (Ólafsson, Livingstone, \& Haddon, 2014), dan setengah dari anak-anak dapat menggunakan tablet secara mandiri pada saat mereka masuk sekolah (Kabali dkk., 2015; Mourlam, Strouse, Newland, \& Lin, 2019). Anak kecil biasanya belajar mengoperasikan perangkat ini dengan mengamati anggota keluarga dan melalui interaksi dengan teman sebayanya (Kumpulainen \& Gillen, 2017).

Kecepatan akses bagi anak-anak dan remaja ke teknologi online, konvergen, seluler, dan jaringan belum pernah terjadi sebelumnya dalam sejarah inovasi dan difusi teknologi. Perubahan ini memberi orang tua, guru, dan anak-anak tugas yang signifikan untuk memperoleh, mempelajari cara menggunakan, dan menemukan tujuan internet dalam kehidupan sehari-hari mereka.

Pesatnya perkembangan teknologi sekarang ini mestinya menjadi kunci utama dalam upaya untuk mengembangkan kemampuan dan keterampilan diri peserta didik dalam bidang pendidikan dan proses pembelajaran dalam menghadapi dunia teknologi dan informasi. Dukungan dan peran pendidikan diharapkan dapat meningkatkan daya saing bangsa di tengah persaingan global. Gelombang besar dunia digital saat ini tak terbendung lagi, yang menghantarkan siapapun yang dapat memanfaatkannya dengan baik namun tak jarang dapat menghancurkan martabat seseorang dengan berbagai cara. Ketidakpahaman manusia pada dunia digital membuat berbagai penyalahgunaan media digital terjadi di level personal, sosial dan nasional. Oleh karena itu, peningkatan kualitas pembelajaran merupakan salah satu tantangan bagi para pelaku pendidikan di Indonesia.(Harian Jurnal Asia, 2016)

Kristiawan, dkk (2018) berpendapat bahwa pendidikan merupakan upaya pengembangan potensi manusiawi dari para peserta didik, baik berupa fisik dan cipta maupun karsa agar potensi tersebut menjadi nyata dan dapat berfungsi bagi perjalan kehidupan. Selain itu, peserta didik seharusnya dilatih dan diajarkan untuk dapat mengembangkan dan membangun pengetahuan yang dimilikinya untuk dapat menyelesaikan permasalahan yang ada dalam kehidupan bermasyarakat,

Mersepon kemajuan teknologi informasi yang begitu pesat tersebut, salah satu organisasi internasional bidang pendidikan yaitu UNESCO memploklamirkan slogan literacy for all meningkatkan kualitas hidup diberbagai lini kehidupan baik secara individu, keluarga ataupun masyarakat dengan harapan akan memberikan multiplier effect sebagai upaya pemberantasan kemiskinan, pengurangan angka kematian pada kelahiran, penghambat pertumbuhan penduduk, pencapaian kesetaraan gender, pembangunan berkelanjutan dan perdamaian (Unesco, 2014).

Keterbukaan teknologi informasi seharusnya diimbangi dengan kemajuan literasi membaca yang baik, namun di Indonesia khususnya, kemampuan literasi membaca bagi anak masih berada diurutan paling bawah. Organisasi untuk Kerjasama Ekonomi dan Pembangunan (OECD) mencatat peringkat Programme for International Student Assessment (PISA) Indonesia berdasarkan survei tahun 2018 berada dalam urutan bawah. PISA sendiri merupakan metode penilaian internasional yang menjadi indikator untuk mengukur kompetensi siswa Indonesia di tingkat global. Untuk nilai kompetensi membaca, Indonesia berada dalam peringkat 72 dari 77 negara.

Oleh karena itu, Pengembangan Literasi digital diharapkan dapat menjadi tolak ukur dan faktor pendukung dalam pengembangan pengetahuan peserta didik yang dapat diakses dengan media-media digital disekitar lingkungannya seperti, handphone, komputer, laptop, dll. 
Gilster (2012) mengemukakan bahwa literasi digital adalah kemampuan menggunakan teknologi dan informasi dari piranti digital secara efektif dan efisien dalam berbagai konteks seperti akademik, karir dan kehidupan sehari-hari. Pendapat Gilster tersebut seolah-olah menyederhanakan media digital yang sebenarnya yang terdiri dari berbagai bentuk informasi sekaligus seperti suara, tulisan dan gambar. Oleh sebab itu Eshet (2002) menekankan bahwa literasi digital seharusnya lebih dari sekedar kemampuan dalam menggunakan berbagai sumber digital secara efektif. Literasi digital juga merupakan bentuk pola berpikir penggguna digital.

\section{METODE}

Metode penelitian menggunakan penelitian deskriptif kualitatif dengan teknik pengumpulan data menggunakan studi kepustakaan teknik simak, dimana salah satu tekniksimak adalah teknik catat. Teknik catat merupakan teknik pengumpulan datadengan cara menggunakan buku-buku,literatur ataupun bahan pustaka, kemudian mencatat atau mengutip pendapat para ahli yang ada di dalam buku tersebut untuk memperkuat landasan teori dalam penulisan artikel ilmiah.

\section{A. Kemampuan Literasi}

\section{HASIL DAN PEMBAHASAN}

Pemerintah mencanangkan pentingnya literasi informasi (information literacy), adalah sebuah kemampuan untuk mencari, memahami, mengevaluasi secara kritis, serta mengelola informasi menjadi sebuah pengetahuan yang bermanfaat untuk pengembangan kehidupan pribadi dan sosialnya.

Menurut Viruru (2003) yang berangkat dari perspektif postkolonial, membagi makna literacy menjadi empat, yakni: (1) literacy as entity (berdiri sendiri serta berada di luar kontrol manusia secara individu maupun lingkup masyarakat); (2) literacy as self (literasi adalah sesuatu dibentuk atau terjadi secara personal) (3) literacy as institution (literasi layaknya mata uang yang bisa bertambah, berkurang, dan menjadi indikator kesuksesan) dan (4) literacy as practice (literasi adalah fenomena aktivitas berbagai manusia yang mengkomparasikan beberapa literasi).

Stokes (2008) juga memberikan empat makna pada istilah literasi. Pertama, literasi adalah kemampuan seseorang untuk membaca dan menulis. Kemampuan dasar ini merupakan prasyarat menuju interaksi sosial. Kedua, membaca, menulis, dan komputasi dalam derajat tertentu yang memungkinkan individu berinteraksi dalam masyarakat yang kompleks. Ketiga, literasi merujuk ke seperangkat kemampuan yang lebih tinggi yang memungkinkan seseorang berpartisipasi penuh dalam sistem sosial, ekonomi, dan politik. Keempat, literasi merupakan karakteristik kelompok sosial atau kelompok budaya tertentu. Seperti bahasa, literasi adalah variasi praktik-praktik budaya yang dimiliki beragam entitas sosial.

\section{B. Literasi Dlgital}

Gilster (2012) mengemukakan bahwa literasi digital adalah kemampuan menggunakan teknologi dan informasi dari piranti digital secara efektif dan efisien dalam berbagai konteks seperti akademik, karir dan kehidupan sehari-hari. Pendapat Gilster tersebut seolah-olah menyederhanakan media digital yang sebenarnya yang terdiri dari berbagai bentuk informasi sekaligus seperti suara, tulisan dan gambar.

Oleh sebab itu Eshet (2004) menekankan bahwa literasi digital seharusnya lebih dari sekedar kemampuan dalam menggunakan berbagai sumber digital secara efektif. Literasi digital juga merupakan bentuk pola berpikir penggguna digital. Lebih lanjut Eshet (2004) mengemukakan Literasi digital melibatkan lebih dari sekadar kemampuan untuk menggunakan perangkat lunak atau mengoperasikan perangkat 
digital; itu mencakup berbagai macam keterampilan kognitif, motorik, sosiologis, dan emosional yang kompleks, yang dibutuhkan pengguna untuk berfungsi secara efektif dalam lingkungan digital. Tugas yang diperlukan dalam konteks ini termasuk, misalnya, "membaca" instruksi dari tampilan grafis di antarmuka pengguna; menggunakan reproduksi digital untuk membuat materi baru yang bermakna dari materi yang sudah ada; membangun pengetahuan dari nonlinier, navigasi hipertekstual; mengevaluasi kualitas dan validitas informasi; dan memiliki pemahaman yang matang dan realistis tentang "aturan" yang berlaku di dunia maya.

Pengembangan kerangka kerja konseptual yang lebih jelas dapat meningkatkan pemahaman keterampilan yang dicakup oleh istilah "literasi digital," dan memberikan para perancang lingkungan digital dengan pedoman yang lebih tepat untuk perencanaan yang efektif dari lingkungan kerja digital yang berorientasi pada pelajar (Hamburger, 2002)

Artikel ini mengusulkan kerangka konseptual baru untuk konsep literasi digital, yang menggabungkan lima jenis literasi: (a) literasi fotovisual; (b) literasi reproduksi; (c) literasi informasi; (d) literasi bercabang; dan (e) literasi sosialemosional. Tinjauan literatur dalam merencanakan lingkungan digital untuk anakanak dan orang dewasa, baik di industri maupun akademisi, menunjukkan bahwa jenis literasi digital ini mencakup sebagian besar keterampilan kognitif yang diterapkan saat menggunakan digital. lingkungan. Dengan demikian, kerangka kerja konseptual ini dapat meningkatkan pemahaman tentang bagaimana pengguna melakukan tugas-tugas yang memerlukan pemanfaatan berbagai jenis keterampilan digital.

\section{Photo-Visual Literasi: Seni Membaca Visual Representasi}

Menulis adalah sarana komunikasi yang menggunakan simbol-simbol; Dalam perjalanan sejarah berkembang dari alfabet gambar, yang menggunakan simbol-simbol dengan makna visual asosiatif untuk mewakili kata, konsonan, atau huruf, dan oleh karena itu diperlukan tingkat mediasi kognitif yang relatif rendah, ke alfabet modern, yang terdiri dari simbol abstrak (huruf) yang "tidak berarti", dan oleh karena itu memerlukan tingkat mediasi kognitif yang lebih tinggi. Sebaliknya, sejarah komunikasi visual dalam lingkungan digital mencerminkan tren yang berlawanan, seperti yang ditunjukkan, misalnya, dalam antarmuka pengguna komputer. Ini dikembangkan dari antarmuka sintaksis berbasis teks, dipandu perintah ke antarmuka pengguna grafis intuitif yang menerapkan prinsip-prinsip "menggunakan visi untuk berpikir" (Mullet \& Sano, 1995; Shneiderman, 1998; Tuft, 1990) dan menciptakan komunikasi foto-visual yang efektif. yang "berbicara dalam bahasa pengguna" (Nielsen, 1993). Penelitian kegunaan (misalnya, Margono \& Shneiderman, 1987) telah menunjukkan bahwa lebih mudah bagi sebagian besar pengguna, pemula dan ahli, untuk belajar dari antarmuka grafis, karena mereka menggunakan komunikasi visual alami dengan pengguna.

\section{Literasi Reproduksi: Seni Daur Ulang Kreatif Bahan yang Ada}

Penemuan mesin cetak oleh Gutenberg (1455) menandai lompatan besar dalam kemampuan manusia untuk menyalin, mereproduksi, dan mendistribusikan informasi dalam skala besar. Sampai saat itu, semua pengetahuan tertulis atau grafis disimpan dengan cara yang tidak dapat direproduksi, di perpustakaan dan koleksi. Beberapa tradisi dan pengetahuan bahkan tidak dalam bentuk tertulis, tetapi diturunkan secara lisan dari orang tua kepada anak-anak. Lompatan besar berikutnya dalam kemampuan manusia untuk mereproduksi pengetahuan terjadi pada abad kedua puluh, dengan munculnya reproduksi digital terkomputerisasi (Benjamin, 1994). Kemungkinan baru dan tak terbatas untuk mereproduksi dan mendistribusikan informasi digital 
telah membuka cakrawala baru bagi para sarjana dan seniman, tetapi mereka juga membutuhkan pengembangan seperangkat kriteria baru untuk orisinalitas, kreativitas, dan bakat dalam karya seni atau akademis.

\section{Literasi Cabang: Hipermedia Dan Pemikiran Non-Linear}

Teknologi hypermedia modern telah menghadirkan tantangan baru bagi pengguna komputer dalam literasi digital (Gilster, 1997). Ini memungkinkan seseorang untuk beralih dari pencarian data yang relatif linier di perpustakaan dan database digital tradisional, ke konstruksi pengetahuan dari informasi yang diakses secara nonlinier. Lingkungan hypermedia modern memberi pengguna tingkat kebebasan yang tinggi dalam menavigasi melalui domain pengetahuan yang berbeda, tetapi juga memberi mereka masalah yang timbul dari kebutuhan untuk membangun pengetahuan dari sejumlah besar informasi independen, dicapai secara nonlinier, "tidak teratur".

\section{Literasi Informasi: Seni Skeptisme}

Dengan pesatnya pertumbuhan akses informasi, kemampuan konsumen untuk mengevaluasi dan menggunakannya secara bijak menjadi isu utama dalam menciptakan konsumen informasi yang teredukasi (Kerka, 1999; Salomon, 2000). Kebutuhan untuk mengevaluasi informasi dengan benar bukanlah hal yang unik di era digital; itu selalu menjadi pusat pembelajaran yang sukses, bahkan sebelum revolusi informasi. Namun, di era modern, dengan paparan informasi digital yang tidak terbatas, yang dapat dipublikasikan dengan mudah dan dimanipulasi tanpa kesulitan, kemampuan untuk mengevaluasi dan menilai informasi dengan benar telah menjadi "kemampuan bertahan" bagi para pengguna informasi.

\section{Literasi Sosial-Emosional}

Perluasan Internet dan platform komunikasi digital lainnya telah membuka dimensi dan peluang baru untuk pembelajaran kolaboratif dan berbagi informasi dalam berbagai bentuk, seperti komunitas belajar, kelompok diskusi, dan ruang obrolan (Scardamalia \& Bereiter, 1996; Mioduser \& Nachmias, 2002). ). Namun, di samping peluang, kemungkinan baru ini juga menghadirkan masalah bagi pengguna, dalam proporsi yang tidak diketahui sebelum era Internet. Misalnya, bagaimana mungkin mengetahui apakah individu di ruang obrolan benar-benar seperti yang mereka katakan? Untuk memperoleh keterampilan ini, pengguna harus sangat kritis, analitis, dan matang, dan harus memiliki tingkat literasi informasi dan literasi percabangan yang tinggi. Banyak penelitian telah dikhususkan untuk menggambar profil sosio-psikologis pengguna di dunia maya

\section{SIMPULAN}

Literasi digital dapat didefinisikan sebagai keterampilan bertahan hidup di era digital. Ini merupakan sistem keterampilan dan strategi yang digunakan oleh pelajar dan pengguna di lingkungan digital. Dengan menggunakan berbagai jenis literasi digital, pengguna meningkatkan kinerja mereka dan "bertahan" berbagai rintangan dan batu sandungan yang menghalangi dalam media khusus ini. Literatur tidak konsisten dalam penggunaan istilah "literasi digital"; beberapa membatasi konsep pada aspek teknis operasi di lingkungan digital, sementara yang lain menerapkannya dalam konteks aspek kognitif dan sosio-emosional bekerja di lingkungan komputer. Artikel ini mengambil langkah pertama untuk membentuk kerangka acuan konseptual integratif yang mencakup sebagian besar dimensi aktivitas pengguna di lingkungan digital, yang dapat berfungsi sebagai dasar untuk penelitian masa depan tentang arah budaya digital yang selalu berubah. Penerapan kerangka kerja ini juga dapat meningkatkan komunikasi di 
antara pelajar dan pengembang, dengan menyediakan alat diagnostik dan evaluatif untuk digunakan dalam menciptakan produk yang tepat dan diarahkan pengguna.

\section{DAFTAR PUSTAKA}

Kim, C., Mirusmonov, M., Lee, I. (2010). An Empirical Examination of Factors Influencing the Intention to Use Mobile Payment. Computers in Human Behavior, 26 (1), 310322.

Edukasi Kompas (2020). Nilai PISA siswa Indonesia. (https://edukasi.kompas.com/read/2020/04/05/154418571/nilai-pisa-siswa-

indonesia-rendah-nadiem-siapkan-5-strategi-ini?page=all, diakses 30 Juli 2021)Eshet, Y. (2004). Digital literacy: A conceptual framework for survival skills in the digital era. Journal of educational multimedia and hypermedia, 13(1), 93106.

Eshet, Y. (2004). Digital literacy: A conceptual framework for survival skills in the digital era. Journal of educational multimedia and hypermedia, 13(1), 93-106.

Gilster, P. (1997) Digital literacy. New York: Wiley.

Kabali, H. K., Irigoyen, M. M., Nunez-Davis, R., Budacki, J. G., Mohanty, S. H., Leister, K. P., \& Bonner, R. L. (2015). Exposure and use of mobile media devices by young children. Pediatrics, 136(6), 1044-1050.

Kristiawan, M., Suryanti, I., Muntazir, M., Ribuwati, A., \& AJ, A. (2018). Inovasi Pendidikan. Jawa Timur: Wade Group National Publishing.

Mourlam, D. J., Strouse, G. A., Newland, L. A., \& Lin, H. (2019). Can they do it? A comparison of teacher candidates' beliefs and preschoolers' actual skills with digital technology and media. Computers \& Education, 129, 82-91.

Ólafsson, K., Livingstone, S., \& Haddon, L. (2014). Children's use of online technologies in Europe: a review of the European evidence base (revised edition).

Stokes, W. (2008). Literacy. In N. J. Salkind \& K. Rasmussen (Eds.), Encyclopedia of Educational Psychology (Vol. 2, pp. 608-616).

UNESCO. (2014). Literacy for All. (Online). (http://en.unesco.org/themes/literacyall, diakses 24 September 2018).

Viruru, R. (2003). Postcolonial Perspectives on Childhood and Literacy. In Handbook of Early Childhood Literacy (pp. 13-22). ELEC, SAGEPublication Ltd. 